\title{
Flavonoids in Helichrysum pamphylicum Inhibit Mammalian Type I DNA Topoisomerase
}

\author{
Zeki Topcu ${ }^{\text {a,*}}$, Bintug Ozturk ${ }^{\mathrm{b}}$, Ozlem Kucukogluc ${ }^{\mathrm{c}}$, and Emrah Kilinc ${ }^{\mathrm{d}}$ \\ a Department of Pharmaceutical Biotechnology, Faculty of Pharmacy, Ege University, \\ 35100 Izmir, Turkey. E-mail: zeki.topcu@ege.edu.tr \\ b Pharmaceutical Botany, Faculty of Pharmacy, Ege University, 35100 Izmir, Turkey \\ c Pharmaceutical Toxicology, Faculty of Pharmacy, Ege University, 35100 Izmir, Turkey \\ d Analytical Chemistry, Faculty of Pharmacy, Ege University, 35100 Izmir, Turkey \\ * Author for correspondence and reprint requests \\ Z. Naturforsch. 63c, 69-74 (2008); received August 3/September 7, 2007
}

DNA topoisomerases are important targets for cancer chemotherapy. We investigated the effects of a methanolic extract of Helichrysum pamphylicum on mammalian DNA topoisomerase I via in vitro plasmid supercoil relaxation assays. The extracts manifested a considerable inhibition of the enzyme's activity in a dose-dependent manner. We also performed a HPLC analysis to identify the flavonoid content of the $H$. pamphylicum extract and tested the identified flavonoids; luteolin, luteolin-4-glucoside, naringenin, helichrysinA and isoquercitrin, on DNA topoisomerase I activity. The measurement of the total antioxidant capacity of the flavonoid standards suggested that the topoisomerase inhibition might be correlated with the antioxidant capacity of the plant.

Key words: Helichrysum pamphylicum, DNA Topoisomerase

\section{Introduction}

The genus Helichrysum of the family Asteraceae consists of approximately 600 species $(\mathrm{Cu}-$ bukcu and Mericli, 1977). This family is represented by 27 taxa, belonging to 21 species among the Turkish flora, out of which fifteen are endemic to Turkey (available at International Herbarium of Ege University, Faculty of Pharmacy, IZEF, Izmir, Turkey; www.izef.ege.edu.tr). Helichrysum species contain considerable amounts of antioxidant (Czinner et al., 2000), antifungal (Barberan et al., 1988), antibacterial and antiviral compounds (Meyer et al., 1996, 1997). These plants are also rich in flavonoids (Webb and Ebeler, 2004). Flavonoids are polyphenolic products with widespread biological properties (Snyder and Gillies, 2003; Webb and Ebeler, 2004). Some flavonoids are abundant in our daily dietary intake (Chowdhury et al., 2002). About twenty flavonoids have been reported to have DNA topoisomerase inhibitory activities to varying extents (Ferguson, 2001; Webb and Ebeler, 2004; Ma et al., 2005).

Topoisomerases are DNA-modifying enzymes found in prokaryotes, eukaryotes, viruses and organelles, such as mitochondria and chloroplasts (Wang, 1996). These enzymes play essential roles in several genetic processes, including DNA repli- cation, transcription, recombination and transposition by introducing or removing DNA superhelical turns, knotting or unknotting, and catenating or decatenating circular DNA molecules. Over the past few years there has been considerable pharmacological interest in these enzymes since DNA topoisomerases were shown to be important targets for chemotherapeutic agents (Topcu, 2001). As part of our work in the search for biologically active compounds, we analyzed Helichrysum pamphylicum and its individual flavonoids for their effects in mammalian DNA topoisomerase I reactions via in vitro supercoil relaxation assays using plasmid substrate, pBR322 (Takara, Otsu-Shiga, Japan). Finally we determined electrochemically the antioxidant capacities of flavonoid standards to identify if they correlate with to the observed activity on the enzyme.

\section{Materials and Methods}

\section{Chemicals}

Luteolin, naringenin, isoquercitrin (quercetin-3glucoside) were obtained as standards from Biochemica (Melbourne, FL, USA). HelichrysinA and luteolin-4-glucoside were isolated from Helichrysum species by Dr. Mericli (Istanbul Univer- 
sity, Turkey). Solvents used for chromatography were methanol and phosphoric acid (HPLC ultragradient grade) supplied by J. T. Baker (Phillipsburg, NJ, USA) and Riedel-de Haen AG (Seelze, Germany), respectively.

\section{Apparatus}

The liquid chromatographic system (Agilent 1100 series, SEM Company, Izmir, Turkey) was equipped with a variable wavelength UV-VIS detector (G1314A), a pump (G1310A Isocratic Pump), a manual injector (G1328A Rheodyne 7725I) with $20 \mu \mathrm{l}$ loop and a chromatographic data processing software (HP ChemStation for LC Rev. A. 06. 03 [509]). Additional electrochemical analyzer used for the determination of the antioxidant capacity was an OMNI-101 Microprocessor Controlled Potentiostat instrument with an electrochemical data processing software (Acquire101SER, version 1.3.1. Cypress Systems Inc., Chelmsford, MA, USA). Electrochemical experiments were carried out in a $10 \mathrm{ml}$ voltammetry cell (BAS VC-2, Bioanalytical Systems Inc., West Lafayette, IN USA). The cell was hermetically sealed with PTFE adapters, to ensure that there was no gas leakage to or from the cell as the solution in the cell was de-oxygenized by pure $\mathrm{N}_{2}$ bubbling before $(1 / 2 \mathrm{~h})$ and during data acquisition when necessary. $\mathrm{An} \mathrm{Ag} / \mathrm{AgCl}$ reference electrode (BAS RE-5B, Bioanalytical Systems Inc.) and a platinum wire auxiliary (BAS, $6 \mathrm{~cm}$ with gold-plated connector) werejoined through the holes in its Teflon cover. Working electrode was a glassy carbon electrode (3.0 $\mathrm{mm}$ diameter.).

\section{Preparation of methanolic extracts}

H. pamphylicum samples were collected during the flowering period from various locations in the years 2000 and 2001. Voucher specimens were identified and deposited at IZEF. The capitules of the plant were dried in shade. $5 \mathrm{~g}$ of flowering tops were suspended in $100 \mathrm{ml}$ of $70 \%$ methanol and extracted under reflux for $3 \mathrm{~h}$ (Carini et al., 2001). Insoluble residue was re-extracted twice using the same solvent and both extracts were combined. The solvent was eliminated by evaporation to dryness under reduced pressure at $60^{\circ} \mathrm{C}$ and the materials were readily obtained as yellow extracts. The dried materials were dissolved in dimethylsulfoxide (DMSO). The yield of the preparations of $H$. pamphylicum extracts was $19.9 \%$.

\section{Chromatographic conditions}

The operating conditions were carried out at $(24 \pm 1)^{\circ} \mathrm{C}$. Separation of the model flavonoids was performed under isocratic conditions with a flow rate of $1 \mathrm{ml} / \mathrm{min}$ for $80 \mathrm{~min}$ on an octadecyl (C18) column (Hichrom $5 \mathrm{C} 18,7.75 \times 300 \mathrm{~mm}$, $5 \mu \mathrm{m}$ particle size). Separated flavonoids were quantified at $230 \mathrm{~nm}\left(\lambda_{\max }\right)$ by a variable wavelength UV-VIS detector. The solvents used and their proportions were (in mobile phase) methanol/0.01 M ortho-phosphoric acid $(50: 50 \mathrm{v} / \mathrm{v})$. Both solvents were degassed (ELMA LC 30/H ultrasonic bath, Hans Schmidbauer GmbH \& Co KG, Singen, Germany) for $30 \mathrm{~min}$ prior to use. Each compound was identified tentatively by its unique retention time under the same conditions. Quantitative determinations were carried out by the external standard method based on peak heigths.

\section{Sample preparation}

A portion of each dried methanolic extract was weighed in the range $30-60 \mathrm{mg}(d=0.1 \mathrm{mg})$ into disposable tubes and dissolved in $4 \mathrm{ml}$ of methanol (HPLC grade) under sonication for $3 \mathrm{~min}$. Each prepared sample solution was then filtered using membranes of $0.45 \mu \mathrm{m}$ pore size $\left(16555\right.$ Minisart $^{\odot}$, Sartorius AG, Goettingen, Germany) and a 100$50 \mu \mathrm{l}$ portion of the filtered solution was finally injected into the HPLC system using a manual injector through a $20 \mu \mathrm{l}$ sample loop.

\section{Electrochemical antioxidant capacity determination}

Differential pulse voltammetry (DPV) was employed for the measurement of the antioxidant capacity, which relies on the electrochemical reduction of dissolved oxygen $\left(\mathrm{O}_{2}\right)$ and the response current linked to this process (Korotkova et al., 2002). The quantification of the antioxidant capacity $(K)$ is based on the ratio of the initial and final response currents $(\Delta I)$ according to

$$
K=\Delta I /\left(I_{\mathrm{Ox}}-I_{\mathrm{Res}}\right) \cdot \Delta C,
$$

where $I_{\mathrm{Ox}}$ is the reduction current of pure dissolved $\mathrm{O}_{2}, I_{\text {Res }}$ the residual current of the solution only, when dissolved $\mathrm{O}_{2}$ is completely removed from the solution by pure Ar or $\mathrm{N}_{2}$ purging. Since at least two different concentrations of antioxidant compounds were studied, $\Delta I$ stands for the difference of response currents of the two different con- 
centrations $\left(I_{2}-I_{1}\right)$ and $\Delta C$ for the concentration difference $\left(C_{2}-\mathrm{C}_{1}\right)$.

\section{Plasmid supercoil relaxation assays}

Plasmid supercoil relaxation assays were carried out as described by Topcu and Castora (1995). Briefly, $20 \mu \mathrm{l}$ of reaction mixture contained one unit of calf thymus recombinant DNA topoisomerase I (Takara, Otsu-Shiga, Japan) and $500 \mathrm{ng}$ of supercoiled (sc) pBR322, in the presence or absence of the extract in $35 \mathrm{~mm}$ Tris- $\mathrm{HCl}$ [2amino-2-(hydroxymethyl)-1,3-propanediol hydrochloride] ( $\mathrm{pH} 8.0$ ), $72 \mathrm{~mm} \mathrm{KCl,} 5 \mathrm{~mm} \mathrm{MgCl}, 5 \mathrm{~mm}$ DTT, $5 \mathrm{~mm}$ spermidine and $0.1 \%$ BSA. A stock solution of $10 \mu \mathrm{g} / \mathrm{ml}$ CPT in DMSO was serially diluted for comparison. The relaxation products were analyzed on $1 \%$ agarose gels in TBE buffer (45 mm Tris borate and $1 \mathrm{~mm}$ EDTA, $\mathrm{pH} \mathrm{8.0)} \mathrm{in}$ a horizontal electrophoresis apparatus $(1 \mathrm{~V} / \mathrm{cm})$ (Thermo EC250) and photographed under UV light after staining with ethidium bromide $(\mathrm{EtdBr})$ $(0.5 \mu \mathrm{g} / \mathrm{ml})$. The relationship between the binding of EtdBr and the amount of fluorescence given by supercoil and relaxed DNAs under UV light was determined as described by Topcu (2000). DNA bands were quantified from gel photographs using the BioRad Multianalysist (Ver: 1.1). One unit of the enzyme activity was defined as the activity removing the supercoils from $500 \mathrm{ng}$ of sc plasmid substrate at $37^{\circ} \mathrm{C}$ in $30 \mathrm{~min}$. All reactions were carried out in DNase-free $1.5 \mathrm{ml}$ microcentrifuge tubes.

\section{Results and Discussion}

In this study we employed an in vitro plasmid supercoil relaxation method to determine the effect of $H$. pamhylicum extracts on the mammalian DNA topoisomerase I activity. The method relies on the ability of topoisomerase I to relax supercoiled DNA (sc DNA), which can be separated as discrete bands using gel electrophoresis. An inhibition of relaxation activity was monitored by the decrease of slower migrating relaxed DNA (rlx DNA) band.

A representative agarose gel photograph of the supercoil relaxation assay in the presence of varying concentrations of $H$. pamphylicum is given in Fig. 1. As shown in the figure, the sc DNA (lane 1) was fully relaxed by the enzyme (lane 2). Relaxation activity of the enzyme was completely inhibited in the presence of 1000 and $500 \mu \mathrm{g} / \mathrm{ml}$ extract

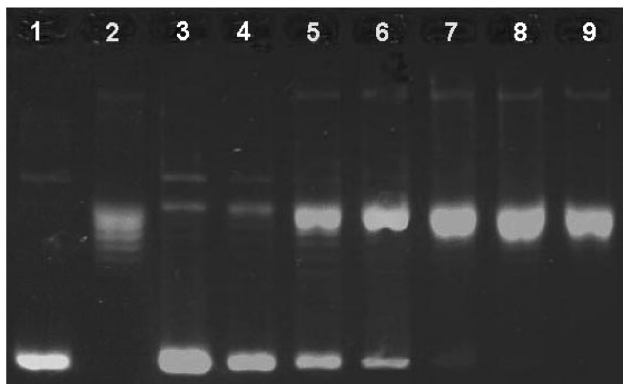

Fig. 1. Representative agarose gel photograph of supercoil relaxation with 1 unit of DNA topoisomerase I in the presence of varying concentrations of $H$. pamphylicum extracts. Lane 1, pBR322; lane 2, pBR322 with $1 \mathrm{u}$ of DNA topoisomerase I; lanes 3-9, pBR322 with $1 \mathrm{u}$ of DNA topoisomerase I in the presence of decreasing concentrations of $H$. pamphylicum extract $(1.0 \mu \mathrm{g} / \mu \mathrm{l}$ to $0.01 \mu \mathrm{g} / \mu \mathrm{l}$ ) (see "Materials and Methods" for details).

(Fig. 1, lanes 3 and 4, respectively). The inhibition was diminished at $250 \mu \mathrm{g} / \mu \mathrm{l}$ and $200 \mu \mathrm{g} / \mu \mathrm{l}$ extract concentrations (Fig. 1, lanes 5 and 6, respectively) as monitored by the appearance of faster-migrating sc DNA with a concomitant decrease in the slower-migrating relaxation products. No inhibition was detected at concentrations lower than $2000 \mu \mathrm{g} / \mu \mathrm{l}$ (Fig. 1, lanes 7-9). Knowing that the organic solvent DMSO has no influence on the reaction, and our assay method can monitor the inhbition sensitively (Kucukoglu et al., 2006), this result shows that $H$. pamphylicum extracts interfere with the DNA topoisomerase I activity. Densitometric quantification of sc and rlx DNA bands showed that the inhibition was dose-dependent (data not shown).

The essential oils, acetylenic and phenolic compounds, carbohydrates, oleic acids and flavonoids are the main chemical constituents of Helichrysum species (Wichtl, 2002; Ma et al., 2005). Among these, flavonoids are of particular importance as some flavonoids were shown to interfere with topoisomerase reactions (Webb and Ebeler, 2004; Ma et al., 2005). Therefore our next attempt was to estimate the flavonoid content of $H$. pamphylicum. Fig. 2 shows typical chromatograms of both flavonoid standards (Fig. 2A) and the methanolic extracts of the Helichrysum species (Fig. 2B) under isocratic conditions with a UV-VIS detector (UVD). The flavonoid standards were found to leave the column in the order: helichrysinA (I), isoquercitrin (II), luteolin-4-glucoside (III), quercetin-4-glucoside (IV), quercetin (V), naringenin 

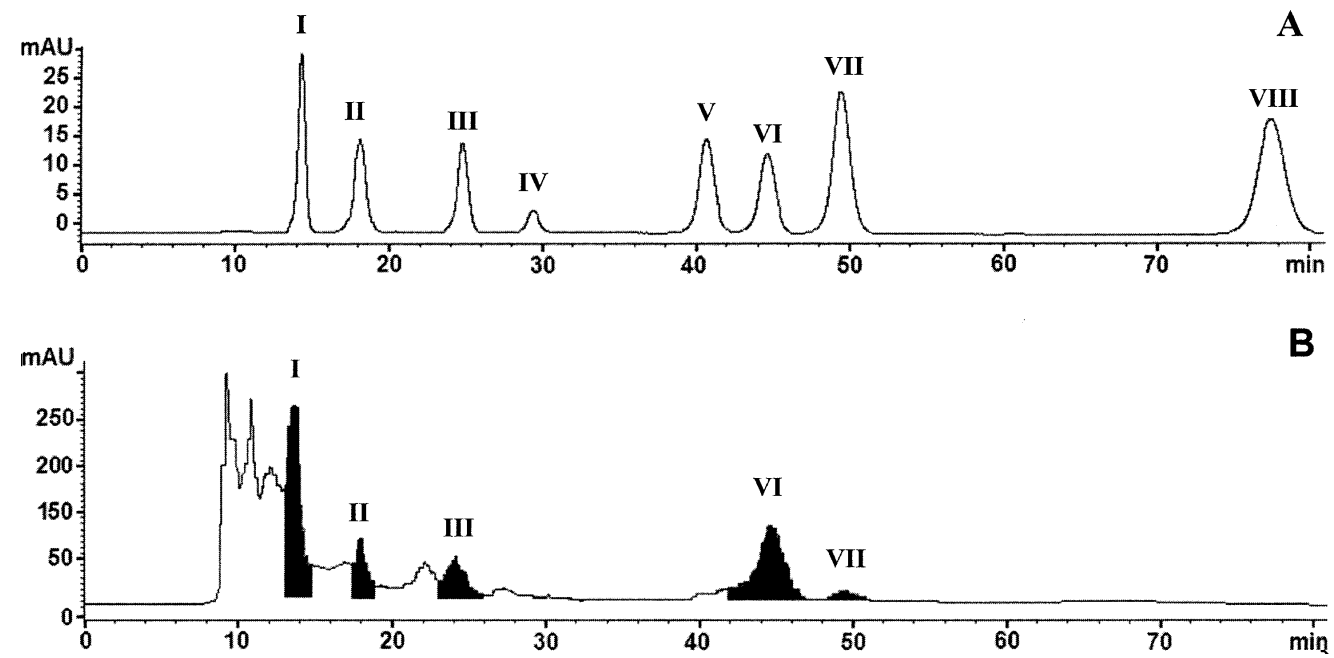

Fig. 2. Typical chromatograms of (A) the model flavonoid standards and (B) the methanolic extracts of $H$. pamphylicum Moench subspecies with a UVD detector. Flavonoid standards appear in the order: I, $25 \mu \mathrm{g} / \mu \mathrm{l}$ helichrysinA; II, $25 \mu \mathrm{g} / \mu \mathrm{l}$ isoquercitrin; III, $26 \mu \mathrm{g} / \mu \mathrm{l}$ luteolin-4-glucoside; IV, $25 \mu \mathrm{g} / \mu \mathrm{l}$ quercetin-4-glucoside; V, $25 \mu \mathrm{g} / \mu \mathrm{l}$ quercetin; VI, $25 \mu \mathrm{g} / \mu \mathrm{l}$ naringenin; VII, $45.92 \mu \mathrm{g} / \mu \mathrm{l}$ luteolin; VIII $45.92 \mu \mathrm{g} / \mu \mathrm{l}$ apigenin (see "Materials and Methods" for details of the experimental conditions).
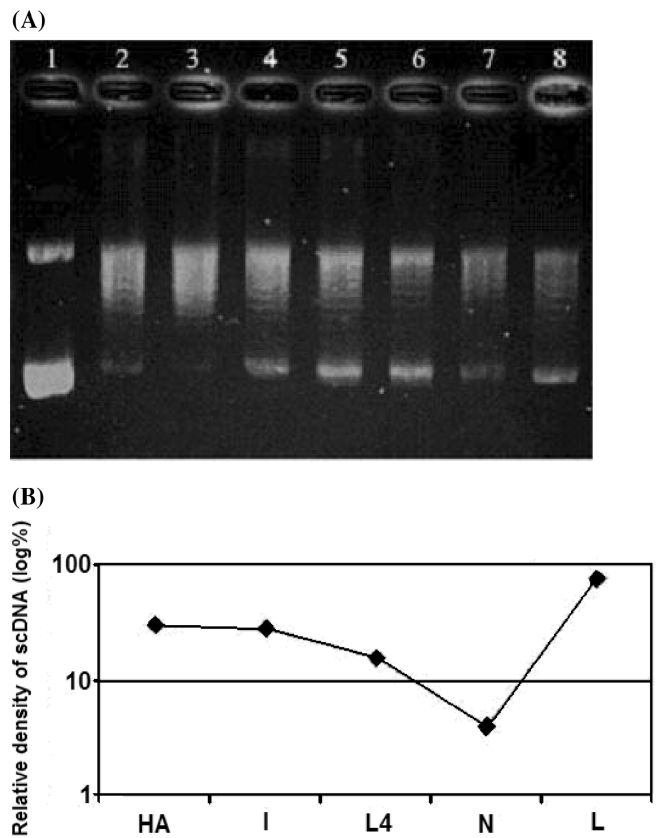

Fig. 3. Effects of the individual flavonoids on DNA topoisomerase I. (A) Agarose gel photograph of the plasmid supercoil relaxation assays in the presence of the individual flavonoids; lane $1, \mathrm{pBR} 322$ only; 2 , pBR322 with DNA topoisomerase I; 3 , same as lane 2 and methanol added; 4, helichrysin A (HA); 5, isoquercitrin (I); 6, luteolin-4-glucoside (L4); 7, naringenin (N); 8, luteolin (L). (B) Quantitative assessment of the inhibition obtained (see "Materials and Methods" for details).
(VI), luteolin (VII) and apigenin (VIII) with the retention times of 14.31, 18.03, 24.71, 29.30, 40.59, 44.55, 49.41 and $77.49 \mathrm{~min}$, respectively (Fig. 2A). Various mixtures of model flavonoids in a linear concentration range (typically $12.5-300.0 \mu \mathrm{g} / \mathrm{ml}$ ) were prepared as the standard solution. Fig. 2A displays the detector responses for the minimum operational range as $25 \mu \mathrm{g} / \mathrm{ml}$ for I, II, IV, V and VI, $26 \mu \mathrm{g} / \mathrm{ml}$ for III, and $46 \mu \mathrm{g} / \mathrm{ml}$ for VII and VIII. The flavonoid content of the methanolic extract, when expressed in percentage (w/w), was as follows: 0.45 (I), 0.49 (II), 0.91 (III), 3.50 (VI) and 0.19 (VII), while quercetin-4-glucoside (IV), quercetin (V) and apigenin (VIII) were not detectable (Fig. 2B). Various peaks present prior to peak I could be defined as chemical compounds with similar apolar characteristics as they were extracted with the same solvent system.

We then included commercial standards of individual flavonoids detected in our HPLC analyses in appropriate concentrations derived from their percentages in the extracts. Fig. 3 shows the inhibitions obtained from the individual flavonoids on supercoil relaxation activity of DNA topoisomerase I (Fig. 3A) and the densitometric values of the inhibition (Fig. 3B). Methanol, used as solvent, did not exert any detectable inhibition on the DNA topoisomerase I activity as the supercoiled DNA (Fig. 3A, lane 1) was relaxed similarly in the reac- 
Table I. Estimated antioxidant capacities of flavonoid standards.

\begin{tabular}{|c|c|c|c|c|c|c|c|c|}
\hline \multirow[t]{2}{*}{ Compound $^{\mathrm{a}}$} & \multicolumn{4}{|c|}{ OH substitution } & \multirow{2}{*}{$\begin{array}{c}\mathrm{C}=\mathrm{O} \\
\text { substitution } \\
\mathrm{C}-4\end{array}$} & \multirow{2}{*}{$\begin{array}{l}\text { Concentration } \\
{[\mu \mathrm{g} / \mathrm{mL}(\mathrm{mm})]}\end{array}$} & \multirow{2}{*}{$\begin{array}{c}\text { Response } \\
\text { current }[\mu \mathrm{A}]\end{array}$} & \multirow{2}{*}{$\begin{array}{c}\text { Antioxidant } \\
\text { capacity }\end{array}$} \\
\hline & $\mathrm{C}-3$ & C-7 & C- $-3^{\prime}$ & C-4' & & & & \\
\hline $\mathrm{L}$ & - & + & + & + & + & $229.6(0.80)$ & +3.167 & 0.298 \\
\hline HA & - & + & - & + & + & $250.0(0.58)$ & +3.307 & 0.252 \\
\hline I & - & + & - & + & + & $250.0(0.54)$ & +3.426 & 0.213 \\
\hline L4 & - & + & + & - & + & $250.0(0.56)$ & +3.719 & 0.117 \\
\hline $\mathrm{N}$ & - & + & - & + & - & $250.0(0.92)$ & +3.889 & 0.062 \\
\hline
\end{tabular}

${ }^{\text {a }}$ L, luteolin; HA, helichrysin A; I, isoquercitrin; L4, luteolin-4-glucoside, N, naringenin.

tions with or without methanol (Fig. 3A, lanes 3 and 2, respectively). Among the components, the highest degree of inhibition was obtained in the presence of luteolin (77\%) (Fig. 3A, lane 8, and Fig. 3B) and the lowest degree of inhibition was obtained in the presence of naringenin $(4 \%)$ (Fig. 3A, lane 7). HelichrysinA (HA), isoquercitrin (I) and luteolin-4-glucoside (L4) gave intermediate inhibitions on the enzyme $(31 \%, 29 \%$ and $16 \%$, respectively) (Fig. 3A, lanes $4-6$ and Fig. 3B). The faint band at the pBR322 lane (Fig. 3A, lane 1) was the residual rlx DNA, and it was taken into consideration by subtracting it from the rlx DNA bands obtained in enzyme reactions (Fig. 3A, lanes 4-8) in densitometric calculations.

We next measured the antioxidant capacities of the flavonoids. We employed an electrochemical method; differential pulse voltammetry (DPV), based on monitoring the reduction current due to the reduction of dissolved oxygen $\left(\mathrm{O}_{2}\right)$ on the surface of the working electrode. The overall redox reaction taking place during $\mathrm{O}_{2}$ reduction is formed of four subsequent sub-reactions. At the end of the first one, a reactive oxygen species (free radical), superoxide $\left(\mathrm{O}_{2}^{-}\right)$, is formed, which, in turn, reacts in the following sub-reactions, and is further reduced to water $\left(\mathrm{H}_{2} \mathrm{O}\right)$. In the presence of a potential antioxidant, $\mathrm{O}_{2}^{-}$is not formed and a drastic decrease in $\mathrm{O}_{2}$ reduction current is observed. When the flavonoid standards were chosen as the model antioxidant compounds, the $\mathrm{O}_{2}$ reduction current values were $+3.17,+3.31,+3.43$, +3.72 and $+3.89 \mu \mathrm{A}$ for L (luteolin), HA, I, L4 and $\mathrm{N}$ (naringenin), respectively (Table I). The corresponding antioxidant capacity values of these flavonoids were calculated as $0.30,0.25,0.21$, 0.12 and 0.06 , which reveals an order of $\mathrm{L}>\mathrm{HA}>\mathrm{I}>\mathrm{L} 4>\mathrm{N}$. Considering their chemical structures, our results suggest that more hy- droxy substitutions cause a stronger antioxidant activity (Table I).

Topoisomerase inhibitors, in general, act at any of the three major steps in the mechanism of mammalian topoisomerase I; enzyme binding to DNA, breakage of DNA strand, or religation of the DNA followed by strand passage (Wang, 1996). A number of studies reported that flavonoids and other polyphenolic compounds inhibit mammalian topoisomerase I through both inhibition of relaxation activity and stabilization of the cleavable complex (poison effect) (Ferguson, 2001; Webb and Ebeler, 2004). Some flavonoids were also shown to intercalate DNA because an association of topoisomerase inhibition with intercalation was noted (Webb and Ebeler, 2004). On the other hand, quercetin and genistein inhibit protein kinases, which are known to affect the topoisomerase activity (Kempuraj et al., 2005). Moreover, both quercetin and luteolin induce DNA cleavage with subsequent DNA ladder formation, a characteristic of apoptosis in HL-60 cells (Yamashita and Kawanishi, 2000). It should also be noted that the components of the Helichrysum species are variable among the sub-species (Cubukcu and Mericli, 1977). Since we observed inhibitions between $76.9 \%$ and $4.0 \%$ with the available individual flavonoids of $H$. pamphylicum, presumably the effect by Helichrysum extracts would have topoisomerase I inhibition of varying degrees due to the difference in their flavonoid compositions. Although the exact mechanism of the inhibition of mammalian DNA topoisomerase I by Helichrysum extracts remains to be clarified, considering the rich flora of Turkey and the geographical distribution of $H$. pamphylicum, this inhibition is a significant result as this plant could be a potential source for developing chemotherapeutics. 


\section{Acknowledgement}

The authors acknowledge Dr. O. Sercan for his help in densitometric quantifications, Dr. M.
Tosun for critical reading of the manuscript and Dr. A. H. Mericli for providing the standards.
Barberan F.-A.-T., Msonthi J.-D., and Hostettmann K. (1988), Antifungal epicuticular methylated flavonoids from Helichrysum nitens. Phytochemistry 27, 753755.

Carini M., Adlini G., Furlanetto S., Stefani R., and Facino R.-M. (2001), LC couplet to ion trap MS for the rapid screening and detection of polyphenol antioxidants from Helichrysum stoechas. J. Pharmaceut. Biomed. Anal. 24, 517-526.

Chowdhury A.-R., Sharma S., Mandal S., Mukhopadhyay S., and Majumder H.-K. (2002), Luteolin, an emerging anti-cancer flavonoid, poisons eukaryotic DNA topoisomerase I. Biochem. J. 366, 653-661.

Cubukcu B. and Mericli A.-H. (1977), Flavonoides d'Helichrysum plicatum DC. Plantes Med. Phytother. 11, 294-302.

Czinner E., Hagymasi K., Blazovics A., Kery A., Szöke E., and Lemberkovics E. (2000), In vitro antioxidant properties of Helichrysum arenarium (L.) Moench. J. Ethnopharmacol. 73, 437-443.

Ferguson L.-R. (2001), Role of plant polyphenols in genomic stability. Mutat. Res. 475, 89-111.

Kempuraj D., Madhappan B., Christodoulou S., Boucher W., Cao J., Papadopoulou N., and Cetrulo C.-L. (2005), Theoharides T. C. Flavonols inhibit proinflammatory mediator release, intracellular calcium ion levels and protein kinase $\mathrm{C}$ theta phosphorylation in human mast cells. Br. J. Pharmacol. 145, 934-944.

Korotkova E.-I., Karbainov Y.-A., and Shevchuk A.-V. (2002), Study of antioxidant properties by voltammetry. J. Electroanal. Chem. 518, 56-60.

Kucukoglu O., Ozturk B., Kamataki T., and Topcu Z. (2006), Inhibitory activities of Helichrysum taxa on mammalian type I DNA topoisomerase. Pharm. Biol. 44, 189-193.
Ma J., Jones S.-H., Marshall R., Wu X., and Hecht S.-M. (2005), DNA topoisomerase I inhibitors from Rinorea anguifera. Bioorg. Med. Chem. Lett. 15, 813-816.

Meyer J.-J.-M., Afolajan A.-J., Taylor M.-B., and Engelbrecht L. (1996), Antibacterial activity of Helichrysum aureonitens (Asteraceae). J. Ethnopharmacol. 52, $41-43$.

Meyer J.-J.-M., Afolajan A.-J., Taylor M.-B., and Erasmus D. (1997), Antiviral activity of galangin isolated from the aerial parts of Helichrysum aureonitens. J. Ethnopharmacol. 56, 165-169.

Snyder R.-D. and Gillies P.-J. (2003), Reduction of genistein clastogenicity in Chinese hamster V79 cells by daidzein and other flavonoids. Food Chem. Toxicol. 41, $1291-1298$.

Topcu Z. (2000), Densitometric quantification of DNA topoisomers in ethidium bromide-stained agarose gels and chemiluminescence-detected X-ray films. Acta Biochim. Pol. 47, 835-839.

Topcu Z. (2001), DNA topoisomerases as targets for anticancer drugs. J. Clin. Pharm. Ther. 26, 405-416.

Topcu Z. and Castora F.-J. (1995), Mammalian mitochondrial DNA topoisomerase I preferentially relaxes supercoils in plasmids containing specific mitochondrial DNA sequences. Biochim. Biophys. Acta 1264, $377-387$.

Wang J.-C. (1996), DNA topoisomeases. Annu. Rev. Biochem. 65, 635-692.

Webb M.-R. and Ebeler S.-E. (2004), Comparative analysis of topoisomerase IB inhibition and DNA intercalation by flavonoids and similar compounds: structural determinates of activity. Biochem. J. 384, 527-541.

Wichtl M. (ed.) (2002), Herbal Drugs and Phytopharmaceuticals. CRC Press, Mepharm Scientific Publishers, Boca Raton, FL, pp. 282-285.

Yamashita N. and Kawanishi S. (2000), Distinct mechanisms of DNA damage in apoptosis induced by quercetin and luteolin. Free Rad. Res. 33, 623-633. 